\title{
DEBATE
}

\section{The biopsychosocial model and its potential for a new theory of homeopathy}

\author{
Josef M Schmidt* \\ Institute of Ethics, History, and Theory of Medicine, University of Munich, Germany
}

\begin{abstract}
Since the nineteenth century the theory of conventional medicine has been developed in close alignment with the mechanistic paradigm of natural sciences. Only in the twentieth century occasional attempts were made to (re)introduce the 'subject' into medical theory, as by Thure von Uexküll (1908-2004) who elaborated the so-called biopsychosocial model of the human being, trying to understand the patient as a unit of organic, mental, and social dimensions of life. Although widely neglected by conventional medicine, it is one of the most coherent, significant, and up-to-date models of medicine at present. Being torn between strict adherence to Hahnemann's original conceptualization and alienation caused by contemporary scientific criticism, homeopathy today still lacks a generally accepted, consistent, and definitive theory which would explain in scientific terms its strength, peculiarity, and principles without relapsing into biomedical reductionism. The biopsychosocial model of the human being implies great potential for a new theory of homeopathy, as may be demonstrated with some typical examples. Homeopathy (2012) 101, 121-128.
\end{abstract}

Keywords: Thure von Uexküll; Jakob von Uexküll; Samuel Hahnemann; Homeopathy; Theory of medicine; Biopsychosocial model

\section{Introduction}

To suggest an option for a new theory of medicine does not necessarily mean to invalidate all previous or existing ones, since their relationship need not to be exclusivist, but may be inclusivist instead. A new theory may just cover a broader range of dimensions, leaving the validity of models for more limited approaches unimpaired. Even though Einstein's theory progressed beyond Newton's physics, the latter remained relevant and indispensable up to the present.

First of all we must affirm that modern natural science has and will keep its legitimate state as a mighty tool for solving problems in many fields and aspects of our lives. We all benefit from scientific progress, from electric light

Revised version of a paper presented at the 1st European Congress of Homeopathy in Riga, Latvia, on 19 May 2011.

*Correspondence: Josef M Schmidt, Institute of Ethics, History, and Theory of Medicine, Ludwig Maximilians University of Munich, Lessingstr. 2, 80336 Munich, Germany.

E-mail: j.m.schmidt@Irz.uni-muenchen.de

Received 19 June 2011; revised 9 January 2012; accepted 6 February 2012 to modern means of transportation and communication. And we are aware of the many prestigious discoveries in cosmology and atomic physics, through space exploration or particle accelerators. The critical point is, however, that on closer inspection many achievements and applications of modern science turn out to be not only advantageous for humanity, but also involve risks and perils, as, for example, with nuclear energy.

Conventional modern medicine faces the same problem, since it relies upon the very same principles and methods as neighboring fields of science. Of course it has distinguished domains of competence and excellence, for example epidemiology, bacteriology, toxicology, etc. It is strong and convincing wherever medical problems can be approached by way of generalization, quantification, and statistical recording. To this end, conventional medical scientists confine themselves to the same reductionist method as used by physicists or chemists: searching for generally accepted natural laws, preferably in terms of causality, mechanism, economics, and efficiency.

They try to explore diseases, effects of medicines, and correlations between parts of the body, as if these were neutral objects or entities, existing independently of a particular context. Ensnared by spectacular successes in controlling 
and commanding life-threatening conditions of the organism and in measuring and manipulating ever smaller structures and functions of cells, genes, and molecules, indeed most scientists, technology writers, and lay persons today are highly tempted to conclude that probably everything in medicine can be explored in such a manner - if not right away, then at least some day in the future.

\section{Conventional medical science}

This widespread attitude of positivism of science, can however be challenged in the field of medicine in a multitude of ways and in fact proves to be untenable, if examined systematically. With the exception of some diseases which can be treated effectively or have been eradicated or whose incidence has greatly declined, many human complaints, especially chronic ailments, can only be palliated, not cured. While for the former the conventional biomedical paradigm is sufficient and adequate, successful treatment of the latter, if possible at all, may need not only more research within customary paths, but new concepts and approaches based on different principles. For the healing of illnesses not satisfactorily managed by conventional medicine, the following reflections and suggestions might be useful.

Putting the criticisms and objections of the reductionist approach in a nutshell, we might say, modern science suffers from amnesia of its own genesis, an unawareness of its blind spot, or an illusion of its autonomy. Scientists are prone to forget that what they are doing is much more than just recording measured data. This can be, and is done, by robots and computers as well. Yet science is a human activity which presupposes human subjects, who are never confined to passive absorption and adaptation to allegedly objective external conditions, but are always also constructing and interpreting the world around themselves. Conducting science, therefore, is not a neutral innocuous undertaking, but inevitably has practical and ethical implications.'

Philosophically speaking, human knowledge is always reliant on underlying notions, concepts, and paradigms, which are brought into play by human minds. But at the same time human knowledge is always in danger of being misled, distorted, or adulterated by the notions, concepts, and paradigms employed. Science, especially modern science which emerged some 300 years ago and has dominated conventional medicine for 150 years, traditionally fixates on a canon of methodological rules and laws. Rather than constantly considering their scope and limits, modern medicine tries to explain as much as possible by means of reduction, subsumption, and generalization.

On the other hand, philosophy, poetry, and art, as well as history and theory of science attempt to rebuff, oppose, and disapprove the superiority and exclusiveness of predominant paradigms and mindsets. They usually try to open up new spaces, create new categories, or claim new liberties to enable the appearance of phenomena which otherwise would not emerge on the horizon and become visible or perceptible at all.
The topic of amnesia of its own genesis on the part of modern science is not a merely theoretical issue, but is of crucial practical relevance. This shortcoming is the origin of many of the problems medicine is facing at present. Modern natural scientists who, for example, are trying to explore the memory of human body and soul, are bound by the scientific method to look for putative objective entities, such as biomolecular engrams, chemical transmitter substances, neuronal flows, brain structures, or the like. They take a distant look at someone else's body. But this is an exoteric view, from outside, the attitude of an alleg. edly neutral observer on an allegedly separate object. The inner dimension of what we call memory, its function, meaning, and dynamics, however, cannot be said to be understood by merely enumerating its necessary physical and chemical conditions. At this point, the category of subjectivity, long-neglected by scientific medicine, claims its legitimate constitutional place in medical theory.

\section{Introducing the subject into medicine}

During the last century, significant attempts have been made to (re)introduce the 'subject' into biology and medicine. ${ }^{3,4}$ So far, however, there is no evidence that this project has unsettled the conventional model of mainstream medicine to any considerable extent. Certainly, (re)introducing the 'subject' into medicine never meant just adding another term to a traditional set of tools and concepts, but rather a paradigmatic change, that is to say, a deconstruction and reconstruction of the fundamental scientific framework.

For centuries, in the wake of Descartes' definition of animals as automats ${ }^{5}$ and De La Mettrie's reification of human beings as machines, ${ }^{6}$ even the so-called life sciences applied the same criteria of scientific research as physicists or chemists. The latter, however, are dealing with dead objects, such as masses, forces, pressures, etc., while the former ought to consider the phenomena of the living. Generally speaking, every branch of scientists tried to reduce the whole world, the animated as well as the inanimate, to mechanical, physical, chemical, mathematical, or statistical laws and causal connections. This had, and still has, a tremendous impact on modern medicine, on our concept of the human being, and on homeopathy.

The ordinary view of man today is determined by the way conventional scientific medicine examines his parts and functions. Accordingly, human beings are deemed to be complicated mechanisms, health is deemed to be their regular and efficient function, and disease is deemed to be their failure, that can be objectified by measured values. As a corollary of the scientific method, drug effects are deemed to be causal impacts on the body, such as chemical reaction, physical suppression, or material substitution. To come to the point, in the conventional scientific approach no difference is made in principle between the causality of drug action in vitro and in vivo. The substance is deemed to execute its determined effect with or without the subject of the patient. 
Taking this setting of coordinates and variables as a basis for the assessment of any kind of medicine, it is clear what, for example, homeopathy will look like. According to evidence-based medicine, the currently dominant tool to implement modern scientific standards in medicine at large, homeopathy as a rule does not fulfill the criteria of biomedical technologies which can be standardised, quantified, and statistically determined. ${ }^{7}$ In a naive analysis, this verdict by leading medical authorities sounds to the general public as if homeopathy had proven not to be scientific at all. ${ }^{8}$ In reality, it discloses only the incompatibility of the conventional scientific method and the practice or art of homeopathy. This, may in turn be interpreted as evidence of failure of the conventional biomedical paradigm rather than a disproof of the homeopathic method of healing.

The challenge for homeopaths, therefore, is rather to find and establish their own scientific theory than to adapt and comply with external standards of conventional medicine. Moreover, the challenge for medicine at large would be to develop a theory of medicine which is wide enough to explain both what conventional and what homeopathic doctors are doing. To be sure, both schools of medicine treat living beings. Hence, any theory that does not imply specific phenomena of the living, such as subjectivity, relationships, and communication, is doomed to fall far short of real life.

\section{The biopsychosocial model of the human being}

In search of a theory of medicine which is comprehensive enough to also provide a conceptual framework for homeopathy, a valuable key may be found in the work of the German physician of Baltic origin Thure von Uexküll (1908-2004), in the 20th century one of the protagonists of the attempt to introduce the 'subject' into medical theory. ${ }^{9}$ From the $1950 \mathrm{~s}$, Uexküll distinguished himself as one of the founders of psychosomatic medicine in Germany, developing and elaborating the so-called biopsychosocial model of human beings, as suggested by George L. Engel. ${ }^{10.11}$ His basic idea and vision were to establish a scientific model of the human being which on the one hand overcomes the reductionism, mechanism, and materialism of the conventional scientific method and on the other enables us to understand the human being as a unity in various aspects: a unity of different levels of existence, such as vegetative, animal, and mental functions, but also a unity between organism and environment, in short between subject and object. ${ }^{12,13}$ Particularly, humans were seen and treated as living beings that answer to signs and do not react to causes.

In conventional science, neither physiologists, psychologists, nor sociologists consider the entire human being, but instead each exclusively applies the method, concepts, and paradigms of his specific field, thus observing different things and talking a different language to that of his colleagues. Contrary to that, Uexküll tried to base his theory on categories broad enough to be applied to all of the different layers, dimensions, and relationships of the patient. To this end, he utilised cybernetic, semiotic, and constructivistic concepts of systems theory. These approaches were developed in control engineering, ${ }^{14.15}$ linguistics, ${ }^{16}$ philosophy, ${ }^{17}$ and psychology, ${ }^{18}$ but not yet introduced into medicine.

Preliminary work, upon which Thure von Uexküll drew heavily, had been done by his father, Jakob von Uexküll (1864-1944), a German-Baltic zoologist and pioneer of theoretic biology. ${ }^{19}$ Born in Estonia, he went to school in Reval (Tallinn), and graduated from the University of Dorpat (Tártu) in 1890. Inspired by his studies of Immanuel Kant (1724-1804) and German and Baltic romantic naturalists, like Johannes Müller (1801-1858) und Karl Ernst von Baer (1792-1876), at the beginning of the 20 th century he conceded a subjective dimension to animals, considering them as organisms answering to signs rather than merely reacting to causes, actually performing 'functional cycles' (1921) within their 'specific environments'. In that way he challenged the traditional supposition of an alleged objectivity which was said to exist independently of particular subjects. ${ }^{20-22}$

It has recently been suggested that Jakob von Uexküll's literary legacy might not be free of racism and anti-Semitism. ${ }^{23}$ In fact his published work contains no explicit anti-Semitic statements. His (unpublished) correspondence, however, does contain some such references but these are virtually confined to a few letters to Houston Steward Chamberlain (1855-1927) during the years 1920-1922, when - caught in an existential (political, social, economic, and professional) crisis - he believed the notorious anti-Semitic forgery 'The Protocols of the Elders of Zion' to be genuine. ${ }^{24-26}$ His few relevant comments on this issue give evidence of his fear of an abstract conspiracy, but never of any consideration of concrete aggression toward individuals. In his important book 'State biology', published in 1920 and 1933, he stressed that 'all human groups must be respected in their distinctiveness' ${ }^{27}$ Aside from cultivating Jewish friendships throughout his life (Beer, Cohnheim, Rothschild, Gross, Trebitsch) ${ }^{28,29}$ and having a Jewish mother-in-law, ${ }^{30}$ Uexküll - unlike most of his colleagues - tried to prevent the dismissal of Jewish professors from German universities in 1933, ${ }^{31}$ argued publicly against racial anti-Semitism in 1936 and $1939,{ }^{32}$ never joined the National Socialist party ${ }^{33}$ or any anti-Semitic organisation (on the contrary, left the German Noble Society because it fell in line with National Socialist racism and anti-Semitism in 1933), ${ }^{34}$ was never involved in human experiments, ${ }^{35}$ and during World War II went into exile on the island of Capri, from 1940 till his death in $1944 .{ }^{36}$ Rather than being a proto-Nazi as has been suggested, Jakob von Uexküll cautiously but successfully tried to distinguish and prevent his biological theory from instrumentalisation of any kind: by vitalist, mechanistic, and social Darwinist ideologies as well as by National Socialist politics. Compared to his contemporaries, his contribution to the history of science may be considered one of the most relevant up to the present: as a forerunner or reference point of sociobiology, cybernetics, biosemiotics, theoretical biology, behaviorism, ecology, systems theory, psychology, and psychosomatic medicine. ${ }^{37}$ 
His son, Thure von Uexküll, was no Nazi either, on the contrary he was one of the first German physicians who after 1945 openly criticised medical wrongdoing during the National Socialist period, as well as the dangerous soullessness of mechanistic medical concepts. ${ }^{38,39}$ His grandson (Thure's nephew), Jakob von Uexküll Jr., a 1944 born Swedish-German journalist, in 1980 founded the Right Livelihood Award, ${ }^{40}$ which in 1996 was awarded to George Vithoulkas - another proof of mental connection between the Uexküll family and homeopathy.

Long before modern constructivists and neuroscientists started to claim that what we call reality is an image, idea, or illusion rather than an objective invariable world which would be one and the same for everybody, ${ }^{41-44}$ Jakob von Uexküll sr. came to similar conclusions by means of his experiments with sea urchins and other marine and terrestrial animals. He demonstrated in an impressive way that every living being constructs and therefore has and commands its own subjective environment. How for example the environment feels or looks to a tick (Ixodida) can be deduced from its sensory and motor organs. The tick can only perceive and react to the sensual qualities of warm or cold, up or down, and, the presence or absence of butyric acid. Accordingly, only such information has a meaning for the tick, while anything else is meaningless, not perceived at all, and thus, never becomes part of its subjective environment. ${ }^{45}$

Apparently, different animals attach different importance to phenomena that they perceive. But even the same individual may attach great importance to something only for a limited time, while at another time the same thing is considered to be unimportant. This difference in assessment depends upon the animal's inner state. When hungry, potential foodstuff gains the highest meaning within the perceptible world. When looking for a sexual partner, however, the perception focuses on different things, thus forming another subjective environment, as long as this preference lasts. The difficult point to understand here is that nobody can really know about anything like a neutral objective reality in which all animals would live and interact. Instead, each one is living in its own subjective environment, which is the result of a permanent construction process, depending on one's own prevailing inner state.

The basic unit of living, therefore, may be conceptualised as a 'functional cycle', consisting of a sensory and a motor branch, with a circular semiotic process. According to its needs, the organism perceives signs from his environment to which he attaches a meaning and reacts in a way that affects and alters these signs, so that their meaning and thus the organism's environment change. Contrary and complementary to conventional causal-mechanic explanations, this new approach to understanding the interactions between animals and their specific environments is based on the concept of subjectivity. Hence, it is hermeneutic rather than deterministic.

Thure von Uexküll, carrying on his father's innovative approach toward a scientific comprehension of the living, elaborated this basic model of a 'functional cycle' for the setting of human beings and supplemented it with the con- cept of a 'situational cycle'. Apart from an increasing complexity regarding additional psychic and social levels, as a major distinction of the human condition, he considered the possibility of the human mind, instead of directly responding to perceived signs, imagining a situation and rehearsing it mentally, without running a risk. To describe this specific human option in terms of systems theory, he coined the concept of a 'situational cycle'.

The real strength of the biopsychosocial model of the human being, however, - apart from considering humans as organisms that answer to signs rather than react to causes lies in the capability to overcome the theoretical as well as institutional separation of physiological, psychical, and social problems of a patient. No matter which level of existence one is considering, be it biological cell function, interaction of organs, psychic communication, or social relationships, the semiotic model of attaching, processing, and transforming meaning of perceived signs and thus continuously reconstructing one's subjective environment, proves to be applicable in all cases. Since each cell, organ, organism, etc. has its own environment, its own order of importance, and its own code to detect and process meaningful signs, interactions between different systems or layers have to be interpreted as translation processes (from one system of codes to another) rather than causalmechanic effects, which in the psychological and social dimension have no explanatory power, anyway.

The consequence of this model of semiotic and cybernetic processes underlying the permanent reconstruction of our environment is that everybody is living in his own individual reality. Construction of a common reality is possible (e.g. between doctor and patient), but needs extra communication and translation of signs between the individuals and their subjective environments. To make things more complicated, each unit of a subject and environment also has its individual history, starting at the point in early infancy where the basic unity had separated for the first time, where both subject and object came into being, emerging out of non-existence, and came into the world.

Tracing back the development of the self, its senses, its first impressions, feelings, and conceptions, to the point where the systemic processes described in the biopsychosocial model were not yet running, but still had to be created and initiated, Uexküll uses the German term 'Stimmung' in order to characterise this original state at the fringe of scientific language and notions. ${ }^{46}$ This notion cannot easily be translated into one single English word, due to its many facets, such as mood, atmosphere, general feeling, sentiment, tone, or tuning.

Thus, a kind of tuning would be the precursor of any unit of communication, as the minimal form of being. Later, by means of socialization of the new born child, this preverbal experience will gradually be translated and transformed from a vegetative, to animal, and human level, when strategies and programs of perception and activities are generated to solve problems.

Conversely, even in adulthood any biopsychosocial state or conflict will always be constituted by a reproduction and realization of this original individual 'Stimmung' and its destiny within the biography of the patient. 


\section{The relevance for homeopathy}

This wording, which in other respects is not customary in conventional hard-core science, may remind the reader of the well-known definition of disease which Samuel Hahnemann (1755-1843) some 200 years ago had introduced while attempting to provide a tentative theory of his new science and art of healing. Disease, he said, is a detuning or derangement ('Verstimmung') of the life-force, using the root of the same German term 'Stimmung'. Accordingly, healing would be the retuning of the detuned lifeforce into its original state of tuning. ${ }^{47,48}$

When Hahnemann tried to explain to his contemporaries in theoretical terms what he had found and what he was doing in practice, the medical theory of his time was just about to abandon traditional notions and concepts, such as semiology, ${ }^{49}$ teleology, ${ }^{50}$ and vitalism, and to embrace modern ideas and programs, such as causality, mechanism, and materialism. Hahnemann, living and operating at the interface of two epochs, availed himself of heterogenous components of medical theory in order to connect to the scientific discourse of that transitional period. This is why some of Hahnemann's conceptions today seem antiquated and outdated, some modern and progressive, and some postmodern, revolutionary, or even perennially valid. ${ }^{51}$

Homeopathy at large, however, is still left wanting a consistent and conclusive theory. In fact, due to the lack of awareness of its theoretical roots, homeopaths easily tend to capitulate when exposed to criticism and try to comply with the demands of what they think is current scientific standard. Traditionally, they are used to think that causes are the most important issue in medical treatment. ${ }^{52}$ To prevent being alienated from one's own practical experience by inadequate theoretical objections, however, a good understanding of the strength and weakness of the respective theory is required. With the biopsychosocial model of the human being today most of the refutations on the part of conventional scientific medicine may be rebutted. That way, a new self-confidence could arise amongst homeopaths whenever they become aware that what they are doing in practice is in full accordance with the most coherent, significant, and up-to-date model of medicine. ${ }^{53}$

As long as one clings to the conceptual framework of conventional medicine, it is virtually impossible to make sense of most of the traditional homeopathic terms and concepts, such as life-force, detuning, dynamic action, semiology, idiosyncrasy, etc. However, since they can be translated into the language of the biopsychosocial model and understood and verified within its framework, the problem lies more on the side of conventional medical theory than on that of the homeopathic method and practice.

In order to prevent misunderstanding and misinterpretation, homeopaths would be well advised to avoid Hahnemann's misleading terms and substitute them by theoretically consistent expressions.

\section{Developing a new theory of homeopathy}

Some examples may illustrate the potential of the biopsycho-social model for a new theory of homeopathy.
- Terms and concepts such as life-force, life-principle, or vital force are incompatible with the methodological reduction of conventional medicine based on mechanism, materialism, and positivism. In the biopsychosocial model, however, there is no problem in admitting vitality as a constitutive dimension of all living phenomena. In fact, its entire theory is based on it. But for theoretical reasons, it is much better to call it intentionality or 'subjectivity'. Conceptualised as autopoietic program of control loops or redefined as an emergent property of a living system, this term can be more easily connected to other sciences. ${ }^{54}$ If reinterpreted from a systems theoretical and semiotic perspective, in fact, Hahnemann's basic idea actually looks quite modern.

- Individual differences in the susceptibility, constitution, and disposition of patients are a fundamental problem for conventional medicine, whose major methodological tests are based on comparison of means tests against the background of the cause-effect-impact paradigm. The fact that human individuals, according to their present state and personal history, respond differently to one and the same substance, however, is entirely compatible with the biopsychosocial model with its basic semiotic process of 'functional cycles'. According to one's inner state (including the memory of past stages of individual development), a patient may at one moment attach high significance to one particular remedy, while at another time, according to his changed state, attaches highest importance to another. A Staphysagria state may not last forever, but might change to a Pulsatilla state, for example.

- While in this case conventional science would focus either on supposed causal effects on the level of molecular biology or jump to psycho-social imputations, such as hypochondriasis, auto-suggestion, or placebo-effect; in the biopsychosocial model the patient is considered as an integral unit and his reaction toward a remedy is understood in a uniform (semiotic and cybernetic) way, covering all his layers of existence simultaneously. Contrary to the conventional paradigm, according to which without material substance no drug effect would be possible, in the biopsychosocial model even the controversy about ultramolecular dilutions is irrelevant. Its starting point is not a putatively objective world of matter, but the subjectivity of the patient who attributes and processes subjective meaning to whatever phenomena he likes or needs, be it material or immaterial information. Not the remedy acts, but the patient! And anyway, he at least has to be accepted as real.

- To make this last point clear, the terminology of medicinal 'potencies', pathogenic 'agents', or morbific 'influences' is highly misleading. It rests on the conventional materialistic assumption (from which Hahnemann could not disengage himself completely), that external entities have causal effects on the patient. Except for overwhelming physical or chemical impacts, as by mechanical violence or high doses of suppressive drugs, in regulatory therapies without the subject of the patient remedies would not be involved in the 'functional cycles' which at every moment constitute the present state of the 
patient. Strictly speaking, the germ is not the protagonist, but the individual subject is the 'agent' who falls ill when exposed to certain things that he associates with morbidity. It is not the remedy that causes the cure, but the individual subject has the potential to react to particular perceptions and meanings of drugs by way of aggravation, amelioration, or healing.

- Although Hahnemann did use these conventional terms, which obscure rather than elucidate his truly semiotic phenomenological approach, on the other hand he repeatedly emphasised the 'dynamic' or 'spirit-like' interaction between patient, pathogen, and remedy. Although his concept of 'dynamic' was vague and blurred, it was absolutely clear to him that homeopathic healing transcends the categories of conventional physical, chemical, mechanical, material, or atomistic thinking, ${ }^{55}$ All the more today's homeopaths should not relapse and waste resources in arguing against conventional causal-mechanical objections and concerns. In spite of its complexity, the dynamics of the semiotic processes underlying drug proving and the art of healing are perfectly represented in the biopsychosocial model.

- To give an example from real life: If a particular individual feels sick after looking at a certain picture, it is not a causal effect of the picture that could be reproduced in double-blind studies or the like, but the individual sensitivity, disposition, history, etc. of the patient and his particular dynamics of attaching and processing meaning to the phenomena he encounters, that tips the scale. Interestingly, Hahnemann literally speaks of 'psychic organs', 56 indicating that he consciously used the same terms and concepts to explain dynamic action on the physical as well as on the psychic level. For conventional medical theory this mix of notions and levels might be a nuisance. In the biopsychosocial model, however, it is understood in principle that the dynamics of the subject are the same on all levels and in all dimensions.

- For Hahnemann the aim of the homeopathic treatment was to restore the patient's health, more precisely, to restore him to the original state in which he was in his healthy days. Importantly, Hahnemann did not mind whether the recovered patient became mild or rough again, good or bad, bashful or shameless, etc. ${ }^{57}$ Contrary to conventional academic science whose traditional job has always been to establish generally valid criteria and rules to impose on everything and everybody, Hahnemann's appreciation of the irreducible individuality of the patient's identity makes him a forerunner of the biopsycho-social model. Ahead of his time, rather than proposing abstract normative ideas of health or the like, Hahnemann was aware that each subject has an individual kernel or tuning which cannot be changed by therapeutic means.

- The biopsychosocial model explains why and how every individual, together with his subjective environment, emerges from a basic tuning ('Stimmung') in early infancy, which in turn will accompany the person in any subsequent state experienced throughout his life. Regardless whether the nascent being originally felt frightened relaxed, curious, greedy, etc., as long as the adult manages to keep his genuine subjective environment coherent, he is healthy. Every subject will forever try to harmonise ('abstimmen') his first imprinted state with the situations and phenomena with which he will interact in his later life. Disability to adjust and match one's own individual tuning and one's subjective environment, would result in disease. If we translate Hahnemann's awkward notion 'life-force' into the dynamics of functional and situational cycles connecting the subject with his environment, we find his basic concept expressed in updated scientific language.

- Finally, major theoretical positions of Hahnemann, like his teleological, deistic, and semiotic reasoning, will remain incomprehensible as long as they are assessed from the view of conventional scientific thinking. From the perspective of the biopsychosocial model, however, it does make sense when Hahnemann maintains that the only scientific approach to the patient's state is through the physician's perception of his signs and symptoms. Also his painstaking practical directions concerning drug proving, case taking, and follow-up can hardly be appreciated against the background of conventional medicine, which for intrinsic reasons would willingly confer this labor on questionnaires, checklists, and computers. With the biopsycho-social model, however, it can be understood and demonstrated, that semiotic cycles are omnipresent and that doctors have to be aware of them, in their empathic relationship to patients as well as when watching the interaction between human beings and the remedy they require.

\section{Conclusion}

To conclude this account of how the biopsychosocial model of the human being could boost homeopathy's long-neglected task of developing a new scientific theory, it may be remembered that theory is not just theory and practice is not just practice. Without always considering the other as well and being aware of the basic unity and dynamic connection of all dualities, as the biopsychosocial model suggests, we would never understand in scientific terms the fundamental interplay between theory and practice, between subjects and their environment, or between the patient and the remedy. Hahnemann obviously understood these things in his heart.

Nevertheless, the theory of homeopathy still lacks coherence ('Stimmigkeit') and conclusiveness. It consists of a wide range of different concepts and contains components of contradictory paradigms. What homeopathy needs is a revision of its theoretical armamentarium, in order to meet the demands of the day, to be able to present itself as a legitimate science, connecting and communicating with neighboring fields of science. ${ }^{58,59}$ As the history of medicine shows, theoretical consistency, plausibility, and persuasiveness are the basis for social, political, and institutional recognition. ${ }^{60}$ As outlined, these aims might be achieved by adopting the biopsychosocial model of the human being as a conceptual framework for a new theory of homeopathy. 


\section{References}

I Schmidt JM. Believing in order to understand: Hahnemann's hierarchisation of values. Homeopathy 2008; 97: 156-160.

2 Schmidt JM. The esoteric and exoteric view of homoeopathy. Two sides of the same coin. Br Hom J 1998; 87: 100-105.

3 Weizsäcker Vv. Gesammelte Schriften. Achilles P, Janz D, Schrenk M, Weizsäcker CFv (eds). Frankfurt am Main: Suhrkamp, 1986-2005.

4 Weizsäcker Vv. Warum wird man krank? . Frankfurt am Main: Suhrkamp, 2008.

5 Descartes R. Discours de la Méthode (1637). Adam C, Tannery P (eds). Oeuvres de Descartes, vol. 6. Paris: Librairie Philosophique J. Vrin, 1973, pp. 55f.

6 De La Mettrie JO. L'homme machine (1748). [Man a machine]. Whitefish, Montana: Kessinger Publishing, 2004.

7 Walach $\mathrm{H}$. Reinventing the wheel will not make it rounder: controlled trials of homeopathy reconsidered. $J$ Altern Complement Med 2003; 9(1): 7-13.

8 Anonymous. The end of homeopathy. Lancet 2005; 366(9487): 690.

9 Bartens W. Der Menschenarzt. Zum 100. Geburtstag von Thure von Uexküll. Süddeutsche Zeitung, 14.03.2008.

10 Engel GL. The need for a new medical model: a challenge for biomedicine. Science 1977; 196(4286): 129-136.

11 Engel GL. The clinical application of the biopsychosocial model. J Med Philos 1981; 6: 101-123.

12 Uexküll Tv. Grundfragen der psychosomatischen Medizin. Reinbek: Rowohlt, 1963.

13 Uexküll Tv, Wesiak W. Theorie der Humanmedizin. Grundlagen ärztlichen Denkens und Handelns. 2nd edn. München, Wien, Baltimore: Urban \& Schwarzenberg, 1991.

14 Wiener N. Cybernetics or control and communication in the machine. Cambridge: Cambridge University Press, 1948.

15 Wiener N. Kybernetik, Regelung und Nachrichtenübertragung im Lebewesen und der Maschine. Düsseldorf: Econ, 1963.

16 Saussure Fd. Grundfragen der allgemeinen Sprachwissenschaft. Berlin: de Gruyter, 1967.

17 Peirce CS. Collected papers of Charles Sanders Peirce. Hartshorne C, Weiss P, Burke AW (eds). Cambridge, Massachusetts: Harvard University Press, 1931-1958.

18 Piaget J. Gesammelte Werke. Stuttgart: Klett, 1975.

19 Mildenberger F. Umwelt als Vision. Leben und Werk Jakob von Uexkülls (1864-1944). Sudhoffs Archiv, Beiheft 56. Stuttgart: Franz Steiner Verlag, 2007.

20 Uexküll Jv. Umwelt und Innenwelt der Tiere. Berlin: Springer, 1909. 2nd edn. Berlin: Springer, 1921.

21 Uexküll Jv. Theoretische Biologie. Berlin: Paetel, 1920. 2nd edn, Berlin: Springer, 1928.

22 Uexküll Jv. Bedeutungslehre. Leipzig: Barth, 1940

23 Kreuder-Sonnen K. Review of: eugenics, race and psychiatry in the Baltic states: a trans-national perspective 1900-1945. Riga 7-8 May 2009. [Humanities and Social Sciences Online] H-Soz-uKult, H-Net Reviews October 2009.

24 Mildenberger F. Umwelt als Vision. Leben und Werk Jakob von Uexkiulls (1864-1944). Sudhoffs Archiv, Beiheft 56. Stuttgart: Franz Steiner Verlag, 2007, pp 95,108-111, 115.

25 Harrington A. Reenchanted science: holism in German culture from Wilhelm II to Hitler. Princeton, New Jersey: Princeton University Press, 1996, pp 60,62f.

26 Harrington A. Die Suche nach Ganzheit. Die Geschichte biologischpsychologischer Ganzheitslehren: Vom Kaiserreich bis zurNew-AgeBewegung. Reinbek bei Hamburg: Rowohlt, 2002, pp 125, 127-129.

27 Uexküll Jv. Staatsbiologie (Anatomie-Physiologie-Pathologie des Staates). Berlin: Paetel, 1920. 2nd edn, Hamburg: Hanseatische Verlags-Anstalt 1933, pp 76. Quoted in: Harrington A. Reenchanted science: holism in German culture from Wilhelm II to Hitler.
Princeton, New Jersey: Princeton University Press, 1996, p 62. Die Suche nach Ganzheit. Die Geschichte biologischpsychologischer Ganzheitslehren: Vom Kaiserreich bis zur NewAge-Bewegung, Reinbek bei Hamburg: Rowohlt 2002, pp 127.

28 Mildenberger F. Umwelt als Vision. Leben und Werk Jakob von Uexkülls (1864-1944). Sudhoffs Archiv, Beiheft 56. Stuttgart: Franz Steiner Verlag, 2007, pp 59f, 63, 70, 146; 59, 69, 70, 84, $101,127,157,175$.

29 Harrington A. Reenchanted science: holism in German culture from Wilhelm II to Hitler. Princeton, New Jersey: Princeton University Press, 1996, pp 63. Die Suche nach Ganzheit. Die Geschichte biologisch-psychologischer Ganzheitslehren: Vom Kaiserreich bis zur New-Age-Bewegung. Reinbek bei Hamburg: Rowohlt, 2002, pp $129 \mathrm{f}$.

30 Mildenberger F. Umwelt als Vision. Leben und Werk Jakob von Uexkülls (1864-1944). Sudhoffs Archiv, Beiheft 56. Stuttgart: Franz Steiner Verlag, 2007, pp 158.

31 Uexküll Gv. Jakob von Uexküll. Seine Welt und seine Unwwelt. Eine Biographie. Hamburg: Wegner, 1964, pp 171-173.

32 Uexküll Jv. Niegeschaute Welten. Die Umwelten meiner Freunde. Ein Erinnerungsbuch. Berlin: Fischer, 1936. 8th edn 1939, Berlin: Fischer, pp 126, 157.

33 Memo 14 April 1944. In: Akte: Goethe-Preis. Hamburger Staatsarchiv, 14 April 1944. Quoted in: Harrington A. Reenchanted science: holism in German culture from Wilhelm II to Hitler. Princeton, New Jersey: Princeton University Press, 1996, p 68; Die Suche nach Ganzheit. Die Geschichte biologischpsychologischer Ganzheitslehren: Vom Kaiserreich bis zur New-Age-Bewegung, Reinbek bei Hamburg: Rowohlt 2002, pp 138.

34 Mildenberger F. Umwelt als Vision. Leben und Werk Jakob von Uexkülls (1864-1944). Sudhoffs Archiv, Beiheft 56. Stuttgart: Franz Steiner Verlag, 2007, pp 149, 158.

35 Mildenberger F. Umwelt als Vision. Leben und Werk Jakob von Uexkülls (1864-1944). Sudhoffs Archiv, Beiheft 56. Stuttgart: Franz Steiner Verlag, 2007, pp 208.

36 Mildenberger F. Umwelt als Vision. Leben und Werk Jakob von Uexkülls (1864-1944). Sudhoffs Archiv, Beiheft 56. Stuttgart: Franz Steiner Verlag, 2007, pp $191 \mathrm{f}$.

37 Mildenberger F. Umwelt als Vision. Leben und Werk Jakob von Uexkülls (1864-1944). Sudhoffs Archiv, Beiheft 56. Stuttgart: Franz. Steiner Verlag, 2007, pp 114, 147, 219f, 226, 231-238, 240.

38 Uexküll Tv, Heubner W, Frank E. Der Arzt an Deutschlands Schicksalswende. Ärztl Wschr 1946; 1: 30-32.

39 Uexküll Tv. Krise der Humanität - Gedanken zum Nürnberger Ärzteprozess. Die Zeit 13 February 1947; 3.

40 Uexküll Jv. Projekte der Hoffnung. Der alternative Nobelpreis. München: Raben, 1990.

41 Glasersfeld Ev. Wissen, Sprache und Wirklichkeit. Arbeiten zum radikalen Konstruktivismus. Braunschweig, Wiesbaden: Vieweg, 1987.

42 Foerster Hv. Sicht und Einsicht. Versuche zu einer operativen Erkenntnistheorie. Braunschweig, Wiesbaden: Vieweg, 1985.

43 Maturana HR, Varela FJ. Der Baum der Erkenntnis. Die biologischen Wurzeln menschlichen Erkennens. Bern, München, Wien: Scherz, 1987.

44 Watzlawick P. Wie wirklich ist die Wirklichkeit? Wahn, Täuschung, Verstehen. München: Piper, 1976.

45 Uexküll Jv, Kriszat G. Streifzüge durch die Umwelten von Tieren und Menschen. Berlin: Springer, 1934.

46 Uexküll Tv, Wesiak W. Theorie der Humanmedizin. Grundlagen ärztlichen Denkens und Handelns. 2nd edn. München: Urban \& Schwarzenberg, 1991, pp 235, 362, 366, 415f (passim).

47 Hahnemann S. Organon der Heilkunst. Neufassung mit Systernatik und Glossar. Schmidt JM (ed). München: Elsevier, 2003. 2nd edn., München: Elsevier, 2006, $§ \S 11,29$. 
48 Hahnemann S. Organon of the medical art [Decker S, Trans.] O'Reilly WB (ed). Redmond, Washington: Birdcage Books, 1996. $\S \S 11,29$

49 Walach H. Homoeopathy as semiotic. Semiotica 1991; 83: 81-95

50 Schmidt JM. Die philosophischen Vorstellungen Samuel Hahnemanns bei der Begründung der Homöopathie (bis zum Organon der rationellen Heilkunde, 1810). München: Sonntag, 1990.

51 Schmidt JM. 200 years Organon of Medicine - a comparative review of its six editions. Homeopathy 2010; 99: 271-277.

52 Walach H. Placebo controls: historical, methodological and general aspects. Philos Trans R Soc Lond B Biol Sci 2011; 366: 1870-1878

53 Egger JW. Das biopsychosoziale Krankheitsmodell. Grundzüge eines wissenschaftlich begründeten ganzheitlichen Verständnisses von Krankheit. Psychol Med 2005; 16: 3-12.

54 Krohn W, Küppers G (eds). Emergenz. Die Entstehung von Ordnung, Organisation und Bedeutung. Frankfurt am Main: Suhrkamp, 1992.
55 Hahnemann S. Organon of the medical art [Decker S, Trans.] O'Reilly WB (ed). Redmond, Washington: Birdcage Books, 1996. §11

56 Hahnemann S. Organon of the medical art [Decker S, Trans.] O'Reilly WB (ed). Redmond, Washington: Birdcage Books, 1996. $\S \S 215 f$

57 Hahnemann S. Organon of the medical art [Decker S, Trans.]. O'Reilly WB (ed). Redmond, Washington: Birdcage Books, 1996. $\S 210$

58 Twenhöfel R. Homöopathie und Schulmedizin. Zur Soziologie eines Konflikts. Heidelberg: Haug, 1994.

59 Schmidt JM. Medizintheoretische und wissenschaftshistorische Perspektiven einer Revision der Materia medica homoeopathica Schweiz Z Ganzheitsmed 2010; 22: 232-238.

60 Unschuld PU. What is medicine? Western and Eastern approaches to healing. Berkeley: University of California Press, 2009. 